Hydrol. Earth Syst. Sci., 16, 2005-2020, 2012

www.hydrol-earth-syst-sci.net/16/2005/2012/

doi:10.5194/hess-16-2005-2012

(C) Author(s) 2012. CC Attribution 3.0 License.

(c) (i)

\title{
Past and future changes of streamflow in Poyang Lake Basin, Southeastern China
}

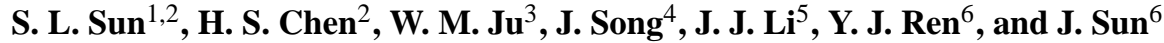 \\ ${ }^{1}$ Applied Hydrometeorological Research Institute, Nanjing University of Information Science \& Technology, Nanjing, China \\ ${ }^{2}$ Key Laboratory of Meteorological Disaster of Ministry of Education, Nanjing University of Information \\ Science \& Technology, Nanjing, China \\ ${ }^{3}$ International Institute for Earth System Science, Nanjing University, Nanjing, China \\ ${ }^{4}$ Department of Geography, Northern Illinois University, Illinois, USA \\ ${ }^{5}$ The Agrometeorological Center of Sichuan Province, Chengdu, China \\ ${ }^{6}$ Wuhan Regional Climate Center, Wuhan, China
}

Correspondence to: H. S. Chen (haishan@ nuist.edu.cn)

Received: 14 September 2011 - Published in Hydrol. Earth Syst. Sci. Discuss.: 24 October 2011

Revised: 24 May 2012 - Accepted: 6 June 2012 - Published: 9 July 2012

\begin{abstract}
To understand the causes of the past water cycle variations and the influence of climate variability on the streamflow, lake storage, and flood potential, we analyze the changes in streamflow and the underlying drivers in four typical watersheds (Gaosha, Meigang, Saitang, and Xiashan) within the Poyang Lake Basin, based on the meteorological observations at 79 weather stations, and datasets of streamflow and river level at four hydrological stations for the period of 1961-2000. The contribution of different climate factors to the change in streamflow in each watershed is estimated quantitatively using the water balance equations. Results show that in each watershed, the annual streamflow exhibits an increasing trend from 1961-2000. The increases in streamflow by $4.80 \mathrm{~m}^{3} \mathrm{~s}^{-1} \mathrm{yr}^{-1}$ and $1.29 \mathrm{~m}^{3} \mathrm{~s}^{-1} \mathrm{yr}^{-1}$ at Meigang and Gaosha, respectively, are statistically significant at the $5 \%$ level. The increase in precipitation is the biggest contributor to the streamflow increment in Meigang $\left(3.79 \mathrm{~m}^{3} \mathrm{~s}^{-1} \mathrm{yr}^{-1}\right)$, Gaosha $\left(1.12 \mathrm{~m}^{3} \mathrm{~s}^{-1} \mathrm{yr}^{-1}\right)$, and Xiashan $\left(1.34 \mathrm{~m}^{3} \mathrm{~s}^{-1} \mathrm{yr}^{-1}\right)$, while the decrease in evapotranspiration is the major factor controlling the streamflow increment in Saitang $\left(0.19 \mathrm{~m}^{3} \mathrm{~s}^{-1} \mathrm{yr}^{-1}\right)$. In addition, radiation and wind contribute more than actual vapor pressure and mean temperature to the changes in evapotranspiration and streamflow for the four watersheds.

For revealing the possible change of streamflow due to the future climate change, we also investigate the projected precipitation and evapotranspiration from of the Coupled Model
\end{abstract}

Intercomparison Project phase 3 (CMIP3) under three greenhouse gases emission scenarios (SRESA1B, SRESA2 and SRESB1) for the period of 2061-2100. When the future changes in the soil water storage changes are assumed ignorable, the streamflow shows an uptrend with the projected increases in both precipitation and evapotranspiration (except for the SRESB1 scenario in Xiashan watershed) relative to the observed mean during 1961-2000. Furthermore, the largest increase in the streamflow is found at Meigang $(+4.31 \%)$ and Xiashan $(+3.84 \%)$ under the SRESA1B scenario, while the increases will occur at Saitang $(+6.87 \%)$ and Gaosha $(+5.15 \%)$ under the SRESB1 scenario.

\section{Introduction}

Water resources are influenced by many aspects of environment (especially climate change, such as precipitation, evapotranspiration and temperature), economy and society (Kundzewicz et al., 2007; Zhang et al., 2007; Nash and Gleick, 1991; Liu and Fu, 1993; Milly et al., 2005; Gedney et al., 2006; Oki et al., 1995). Meanwhile, water resources also have a potential to severely affect environmental quality, economic development and social well-being (Kundzewicz et al., 2007; Zhang et al., 2007). As an important part of the water cycle, streamflow changes can significantly affect water resources, society safety and ecosystem health (Oki and

Published by Copernicus Publications on behalf of the European Geosciences Union. 
Kanae, 2006). Therefore, it can be used as an indicator of climate change owing to the intimate linkage between the water cycle and climate.

It was shown in the Intergovernmental Panel on Climate Change (IPCC, 2007) that the average global temperature increased by $0.74 \pm 0.18^{\circ}$ in the past $100 \mathrm{yr}$, which impacted on the natural ecosystems and environment significantly. In addition, climate change may even be speeded up in the future, consequently leading to an increase in probabilities of floods and droughts. Therefore, changes in water resources and the underlying driving forces due to climate changes have become research focuses (Andréasson et al., 2004; Christensen and Lettenmaier, 2007; Frederick and Major, 1997; Gül et al., 2010; Lins and Slack, 1999; Liu and Cui, 2009; Null et al., 2010; Piao et al., 2007; Thodsen, 2007; Vörösmarty et al., 2000; Xu et al., 2010; Zhang et al., 2001). Andréasson et al. (2004) discussed the impacts of climate change on streamflow under three anthropogenic $\mathrm{CO}_{2}$ emission scenarios with a hydrology model (HBV) and concluded that the influences of climate change based on hydrology cycle varied geographically. Lins and Slack (1999) applied the nonparametric Mann-Kendall test to study temporal trends of streamflow at 395 gauging stations across the USA and suggested that streamflow increased in most regions, except for the northwest and the southeast Pacific. Zhang et al. (2001) pointed out that streamflow decreased significantly in most months, especially in August and September from 19471996 in southern Canada. Xu et al. (2010) analyzed the trends of major hydroclimatic variables from 1960-2007 in the Tarim River Basin of China and concluded that the impacts of increasing air temperature on streamflow showed different characteristics, depending on location and seasons. An increase in temperature tends to increase surface runoff, especially in mountainous regions due to the enhanced snowmelt and glacier melt in the spring, but to decrease the runoff in plain areas because of the increase in the actual evapotranspiration in the summer.

Over the last century, the average temperature in China has experienced a dramatic increase (Ding and Dai, 1994; Zhai et al., 2004; Zhang et al., 2005; Yang et al., 2010; Li et al., 2010), leading to an increase in areas with severe water stress (the Standing Committee of the National People's Congress - NPC - of the People's Republic of China, 1994). The Yangtze River Basin is one of the most advanced economic regions in China and has been affected by flooding seriously and frequently. As the temperature and precipitation increased, the frequency and intensity of floods in this basin showed dramatic increase over the past few years (Hu et al., 2007), resulting in serious economic losses. The projected increase of $2.7^{\circ} \mathrm{C}$ in temperature in the 21 st century will induce precipitation and streamflow to increase by $10 \%$ (Gao et al., 2001) and $37 \%$ (IPCC, 2001), respectively, and the extreme events of rainfall may take place more frequently. Moreover, the occurrence probability of the most serious floods occurring in periods of 10-, 100-, 1000-yr, and even longer (e.g. floods in 1870, 1954 and 1998) may increase. Poyang Lake, as the largest freshwater lake in China, is the reservoir of floods in the middle and lower reaches of the Yangtze River. Its capacity of flood diversion has decreased continuously due to ecological and environmental degradation (e.g. the serious soil and water losses, and the reduction of lake areas and volume). The surface area of this lake shrunk by $25 \%$ and its capacity decreased by $22 \%$ from 1954-1998 (Jiang, 2007), consequently resulting in high vulnerability of the basin to floods. Both droughts and floods have occurred frequently and alternatively over the basin in recent decades. Furthermore, floods have increased in severity since 1990. In the summers of 1998, 1996, and 1995, the basin experienced three of its most severe floods (in descending order) in the last $50 \mathrm{yr}$ (Wang and Dong, 2000; Jiang and Shi, 2003; Shankman et al., 2006).

Recently, the responses of hydrological cycle in the Yangtze River Basin to climate change have been causing more attention. The trend test and change-point analysis have been carried out using the annual maximum, annual minimum and annual mean discharge rates recorded at the Yichang gauging station during the period of 1882-2001 by Xiong and Guo (2004). They reported that at the $5 \%$ significance level, the annual maximum discharge rate did not have any statistically significant trend, but the annual minimum and the annual mean discharge rates significantly decreased by $8 \%$ and $6 \%$, respectively. Applying the SWAT (Soil and Water Assessment Tools) model in Poyang Lake Basin of China, Guo et al. (2008) studied the annual and seasonal responses of streamflow to climate and the land-use changes and revealed that climate had a dominant effect on annual streamflow compared with the impacts of land-use changes, but the land-use changes could strongly influence seasonal variations of streamflow and alter the annual hydrograph of this basin. Chen et al. (2007) found that the mean annual, spring and winter runoff decreased at the $5 \%$ significance level in the Hanjiang Basin, caused by the integrated effects of changes in both precipitation and temperature. They also projected the increasing trends of runoff during the period of 2021-2050 under three climate scenarios of greenhouse gases emissions using a two-parameter water balance model. Zhao et al. (2009) declared that streamflow was more sensitive to precipitation variations than to potential evapotranspiration variations in Poyang Lake Basin.

In summary, most of the previous studies focused on qualitatively analyzing the effects of long-term variability of climate variables, particularly precipitation and temperature on water resources. However, the influences of other climatic variables, such as radiation, wind speed, and vapor pressure, on the past water cycle have not been studied thoroughly. Understanding the causes of water cycle variations clearly and systematically, it is necessary to examine the impacts of each climate variable on the streamflow variation. Knowing these responses, we can address the questions on how the on-going climate change may have influenced the streamflow, lake 


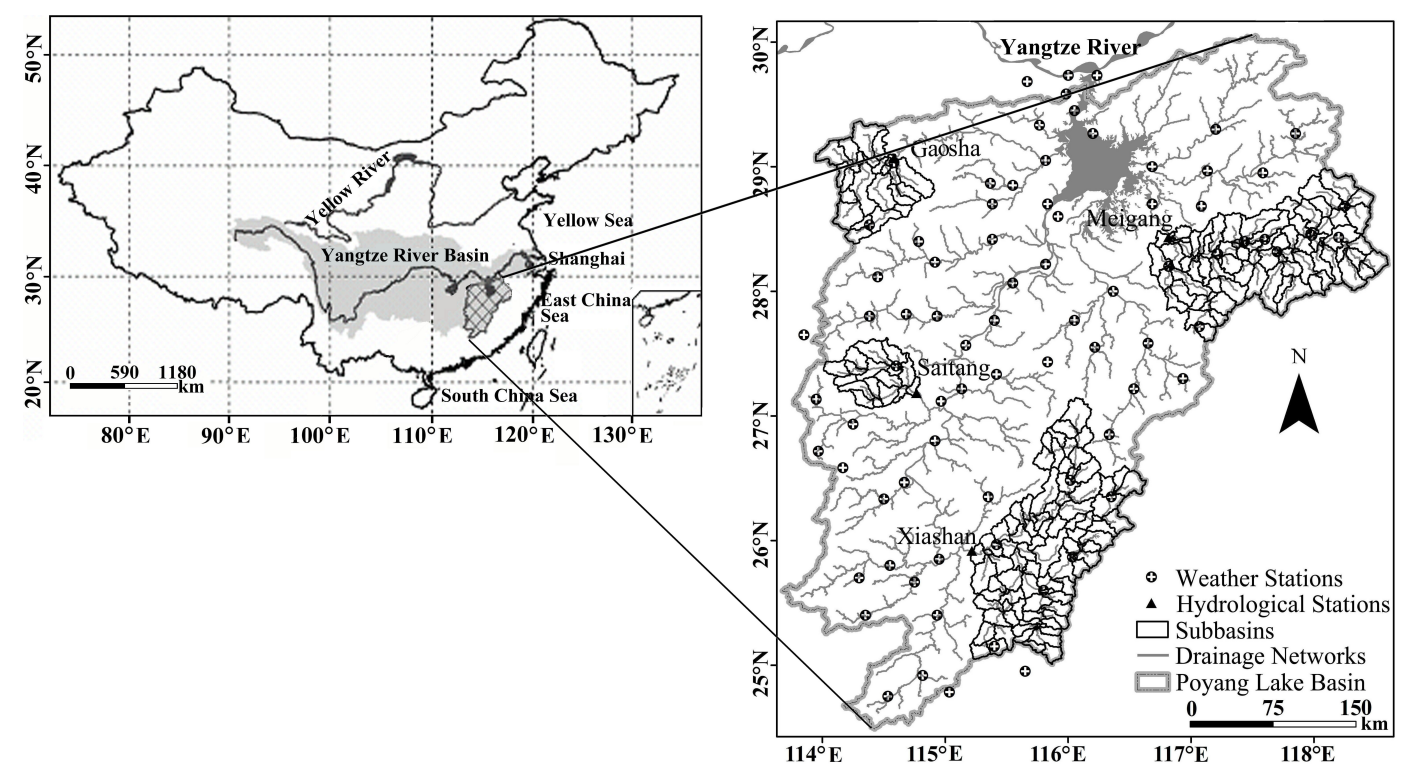

Fig. 1. The geographical location of the study region, Poyang Lake Basin in southern China. 79 weather stations and 4 gauge stations are also shown.

storage, and flood potential in the past, and how the water cycle will vary with the future climate change. These problems are particularly important for water resources exploitation and utilization, agriculture production, and economy development. Therefore, the present study aims to: (1) quantify the contributions of various climate variables to the past (1961-2000) streamflow trends in Poyang Lake Basin on the basis of water balance equations, and (2) project the percentage changes of the streamflow in the future (2061-2100) relative to the past, using the precipitation and evapotranspiration data projected by different global coupled atmosphere-ocean general circulation models (AOGCMs) under three greenhouse gases emission scenarios.

\section{Study region, data used and methods}

\subsection{Study region}

Poyang Lake Basin is located in the middle reaches and the south bank of the Yangtze River, China, covering in total an area of $1.6 \times 10^{5} \mathrm{~km}^{2}$, occupying nearly $96.85 \%$ of the land mass of Jiangxi Province and accounting for $9 \%$ of the Yangtze River Basin (Fig. 1). The size of the lake water body changes seasonally. It can exceed a maximum area of $4000 \mathrm{~km}^{2}$ in the summer and shrink to less than $3000 \mathrm{~km}^{2}$ in the fall and the winter. This lake receives water primarily from Ganjiang River, Xiushui River, Fuhe River, Raohe River, and Xinjiang River. The topography in Poyang Lake Basin is diverse, including mountains, hills, and alluvial plains. Mountains are mainly located in the western and eastern parts with a maximum elevation of $1800 \mathrm{~m}$ a.s.l. (above the sea level), while low alluvial plains are primarily in its central areas, mainly distributed in areas along Ganjiang River.

Four typical watersheds within Poyang Lake Basin were selected for studying the historical trends of streamflow. They are Meigang, Xiashan, Saitang, and Gaosha watersheds, located in the northeast, southeast, middle-west, and northwest parts of this basin (Fig. 1), respectively. The boundaries of watersheds were delineated using the hydrological analysis tools of ArcGIS 9.2 software package based on the $90 \mathrm{~m}$ STRM Version1 (http://dds.cr. usgs.gov/srtm/) Digital Elevation Model (DEM) data. The drainage areas for Meigang, Saitang, Gaosha and Xiashan, are $1.53 \times 10^{4} \mathrm{~km}^{2}, 3.07 \times 10^{3} \mathrm{~km}^{2}, 5.22 \times 10^{3} \mathrm{~km}^{2}$ and $1.59 \times 10^{4} \mathrm{~km}^{2}$, respectively.

The study area belongs to the subtropical monsoon climate zone, and it has a temperate and humid climate with abundant sunlight. Temperature and precipitation both exhibit distinct seasonality (Fig. 2). Among the four watersheds, monthly mean temperature (the left panel of Fig. 2a) increases from January to July and then decreases. The annual mean temperature during $1961-2000$ was $16.6^{\circ}$ in Saitang watershed, while it was above $17.9^{\circ}$ in the other three watersheds. Monthly total precipitation (the left panel of Fig. 2b) increases quickly from January to June and then decreases sharply. During 1961-2000, the annual precipitation in Meigang and Saitang watersheds is about $1640 \mathrm{~mm}$, while in Gaosha and Xiashan watersheds is about $1690 \mathrm{~mm}$. 


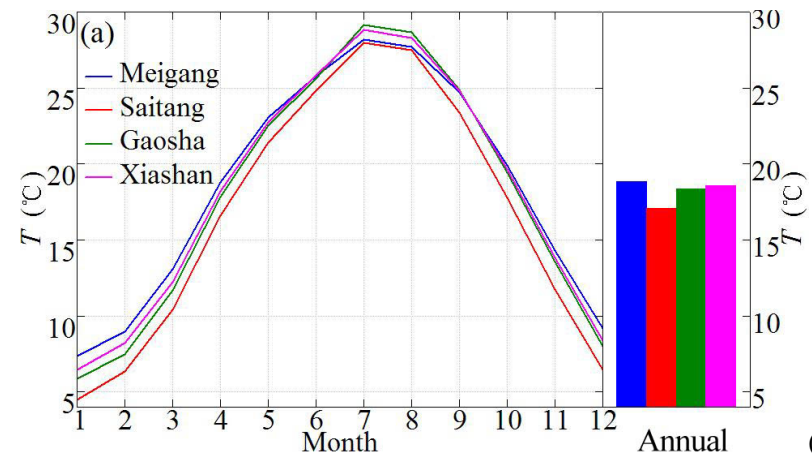

(a)

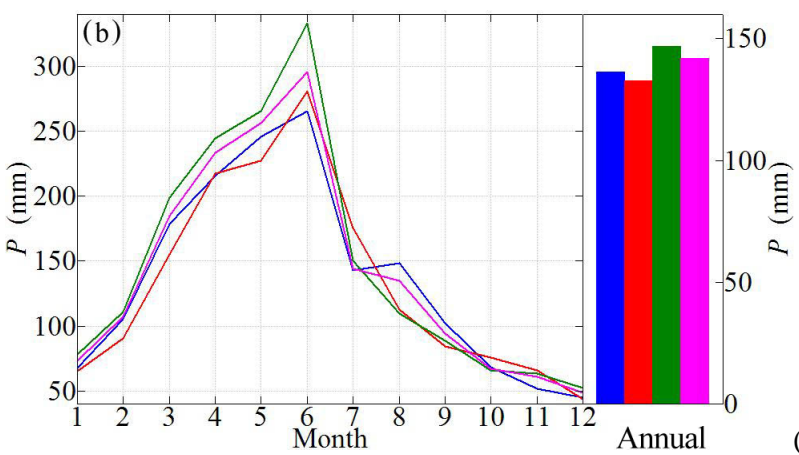

(b)

Fig. 2. Monthly and annual mean temperatures (a) and precipitation (b) averaged during the period from 1961-2000 for the four typical watersheds in the study region.

\subsection{Data}

\subsubsection{Meteorological and hydrological data}

The daily meteorological data during 1961-2000 from 79 weather stations (6 stations are outside Poyang Lake Basin) are used in this study (Fig. 1), including daily precipitation $(\mathrm{mm}), 20 \mathrm{~cm}$ caliber pan evaporation $(\mathrm{mm})$, sunshine percentage $(\%)$, wind speed $\left(\mathrm{m} \mathrm{s}^{-1}\right)$, maximum temperature $\left({ }^{\circ} \mathrm{C}\right)$, minimum temperature $\left({ }^{\circ} \mathrm{C}\right)$, mean temperature $\left({ }^{\circ} \mathrm{C}\right)$, actual water vapor pressure $(\mathrm{kPa})$, and relative humidity of air (\%). As there are only 2 weather stations with radiation observed in the study region, the methods proposed by Wang (2006) and Tong (1989) are used to calculate daily total incoming solar radiation $\left(\mathrm{MJ} \mathrm{m}^{-2} \mathrm{day}^{-1}\right)$ and long-wave radiation $\left(\mathrm{MJ} \mathrm{m}^{-2} \mathrm{day}^{-1}\right)$, respectively. The net radiation $\left(\mathrm{MJ} \mathrm{m}^{-2} \mathrm{day}^{-1}\right)$ is calculated as the difference between the total incoming solar radiation and the long-wave radiation. The Spline Function Method in the ArcGIS 9.2 platform is employed to interpolate the annual mean/total values of climate variables at 79 stations into a dataset at the resolution of $1 \times 1 \mathrm{~km}$. The time series of regional means of climate variables for each watershed are calculated for the period from 1961-2000 to assess the impacts of climate on the streamflow.
Hydrological data used in this study include daily streamflow $\left(\mathrm{m}^{3} \mathrm{~s}^{-1}\right)$ and river level $(\mathrm{m})$ measured at Meigang, Saitang, Gaosha, and Xiashan hydrological stations (Fig. 1).

\subsubsection{Data for the future climate scenarios}

Simulations of AOGCMs for 20th century (20C3M) and 21 st century climate were collected from the Couple Model Intercomparison Project phase 3 of (CMIP3). The 21st century simulations are used to project the changes of streamflow and climate during the period of 2061-2100. The 20 th century climate $(20 \mathrm{C} 3 \mathrm{M})$ was simulated with the contemporary climate scenario, whereas the future climate was projected under three different scenarios of greenhouse gasses emission, including medium greenhouse gases emission scenario (SRESA1B), high greenhouse gases emission scenario (SRESA2), and low greenhouse gases emission scenario (SRESB1). For the future climate simulations, there is no detailed data for some variables (e.g. wind speed and vapor pressure). Therefore, only the monthly mean precipitation and evapotranspiration (converted from monthly latent heat fluxes) from the different AOGCMs under the three emission scenarios are used to estimate the percentage changes of future streamflow relative to the past. We chose only those model outputs with precipitation and latent heat flux and having data up to 2100 . The selected AOGCMs and their resolutions are listed in Table 1 . The details about these models and their outputs can be found at the website of http://www-pcmdi.llnl.gov/ipcc/ model_documentation_ipcc_model_documentation.php.

\subsubsection{Other data}

The land use/land cover dataset in 1995 was downloaded from Environmental \& Ecological Science Data Center for West China, National Natural Science Foundation of China (http://westdc.westgis.ac.cn). The SPOT VGT-NDVI datasets in 1999 and 2000 were from the VITO archive (http://www.vgt.vito.be). The spatial resolutions of these two datasets are $1 \times 1 \mathrm{~km}$. Additionally, a global long-term (1983-2006) 10-day evapotranspiration record with the resolution of $8 \times 8 \mathrm{~km}$ (http://www.ntsg.umt.edu/project/et) was collected. Zhang et al. $(2009,2010)$ indicated that this dataset can capture observed spatial and temporal variations at the global and watershed scale. It can be used as the observational data for evaluating the simulations of actual evapotranspiration with Eq. (3) in the present study.

\subsection{Methods}

\subsubsection{Temporal trends detection}

The trends of hydrometeorological variables are fitted using the linear equation:

$\hat{x}_{t}=f_{0}+f_{1} \cdot t(t=1,2, \ldots, n)$ 
Table 1. Global coupled atmosphere-ocean general circulation models (AOGCMs) and their 20th century climate (20C3M) simulations and 21 st century climate projections used in this study.

\begin{tabular}{|c|c|c|c|c|c|}
\hline \multirow[t]{2}{*}{ Models } & \multirow[t]{2}{*}{ Resolution } & \multirow[t]{2}{*}{$\begin{array}{c}20 \mathrm{C} 3 \mathrm{M} \\
(1961-2000)\end{array}$} & \multicolumn{3}{|c|}{$\begin{array}{l}\text { Three greenhouse gases emission } \\
\text { scenarios }(2061-2100)\end{array}$} \\
\hline & & & SRESA1B & SRESA2 & SRESB1 \\
\hline cccma_cgcm3.1_t63 & $128 \times 64$ & $*$ & $*$ & & $*$ \\
\hline mpi_echam5 & $192 \times 96$ & $*$ & $*$ & $*$ & $*$ \\
\hline miub_echo_g & $96 \times 48$ & $*$ & $*$ & & $*$ \\
\hline miroc3_2_medres & $128 \times 64$ & $*$ & $*$ & $*$ & $*$ \\
\hline miroc3_2_hires & $320 \times 160$ & $*$ & * & & $*$ \\
\hline ipsl_cm4 & $96 \times 72$ & $*$ & $*$ & $*$ & $*$ \\
\hline inmcm3_0 & $72 \times 45$ & $*$ & $*$ & * & $*$ \\
\hline ingv_echam4 & $320 \times 160$ & $*$ & $*$ & $*$ & \\
\hline giss_model_e_r & $72 \times 46$ & $*$ & * & $*$ & * \\
\hline giss_aom & $90 \times 60$ & $*$ & $*$ & & $*$ \\
\hline gfdl_cm2_0 & $144 \times 90$ & $*$ & * & * & $*$ \\
\hline
\end{tabular}

* denotes that the climate simulated or projected by a model was used in this study.

where $\hat{x}_{t}, f_{0}, f_{1}$, and $t$ represent the fitted value of the variable, intercept, temporal variability, and time, respectively; $n(n=40)$ is the sample size. A positive value of $f_{1}$ indicates an increasing trend, and vice versa. A larger magnitude of $f_{1}$ denotes a stronger increasing or decreasing trend. The Student's t-test is used to examine the significance level of a trend. The p-value tells the probability of whether the linear trend value is statistically significantly different from zero.

\subsubsection{Water balance for a watershed}

The study region is located at subtropical climate zone with rare snowfall. Therefore, the water balance for a watershed is calculated as

$R=a \cdot P-E+\Delta W+q$

where $R$ is the streamflow (the sum of surface and underground runoff) measured at the outlet of a watershed. $a$ is the ratio of throughfall to total precipitation above canopy, and it depends on canopy density and rainfall intensity. Because a certain amount of rainfall is intercepted by vegetation canopy (Crockford and Richardson, 2000; Hölscher et al., 2004; Huang et al., 2005), the intercepted rainfall is not involved in the process of runoff yield. Only the throughfall affects the streamflow. $P$ is the precipitation amount. $\Delta W$ is the change of water storage in the watershed. $q$ is the water consumption from the watershed. In reality, $q$ is small in a closed watershed and it is assumed to be zero here for similarity. $E$ is the actual evapotranspiration, and can be calculated from the $20 \mathrm{~cm}$ caliber pan evaporation measurements:

$E=b \cdot E_{\text {pan }}$

where $b$ is the coefficient converting pan evaporation to actual evapotranspiration; $E_{\text {pan }}$ is the evaporation measured with the $20 \mathrm{~cm}$ caliber pan.
In the study region, as precipitation shows considerable interannual variability due to the monsoon climate. The interannual variations of water storage can not be ignored in the calculation of water balance for a watershed using Eq. (2). However, there is not any observation of water storage available at the watershed level. It is known that a tight linkage exists between long mean soil water storage and river level at the outlet in a watershed. In wet periods, both soil water storage and river level are expected to increase, and vice versa. Therefore, the change in river level can be used as a proxy for the change of soil water storage in a watershed to some extent. As an approximation, we use the intra-annual variability of river level $(\Delta \mathrm{WL})$ as a surrogate of $\Delta W$. To weaken the intense low-frequency turbulence in daily river level observations, $\Delta \mathrm{WL}$ is defined as the difference between the mean water level of the last 10-day in December and that of the first 10-day in January in the same year. $\Delta W$ is calculated as

$\Delta W=c \cdot \Delta \mathrm{WL}$.

When the study time period $(n)$ is long enough, $\Delta W$ satisfies the following equation:

$\frac{1}{n} \sum_{i=1}^{n} \Delta W_{i}=\frac{1}{n} \sum_{i=1}^{n}\left(c \cdot \Delta \mathrm{WL}_{i}\right) \approx 0$.

After the units conversion, Eq. (2) can be rewritten as

$$
\begin{aligned}
& R_{\mathrm{yr}}=\left(a \cdot P_{\mathrm{yr}} / 1000-b \cdot E_{\mathrm{pan}, \mathrm{yr}} / 1000+c \cdot \Delta \mathrm{WL}_{\mathrm{yr}}\right) \\
& \quad \cdot A /(\mathrm{yd} \cdot 24 \cdot 3600)
\end{aligned}
$$

where $R_{\mathrm{yr}}\left(\mathrm{m}^{3} \mathrm{~s}^{-1}\right), P_{\mathrm{yr}}(\mathrm{mm})$, and $E_{\mathrm{pan}, \mathrm{yr}}(\mathrm{mm})$ represent the annual mean streamflow, the annual total precipitation and pan evaporation, respectively. $\Delta \mathrm{WL}_{\mathrm{yr}}(\mathrm{m})$ denotes the intra-annual variability of river level at one year; $A\left(\mathrm{~m}^{2}\right)$ is 
the watershed area; yd (day) is the number of days within one year; $a, b$ and $c$ are parameters to be optimized using the observed hydrological and climate data.

\subsubsection{Contribution of different climate variables to the past streamflow changes}

Evapotranspiration is a key component of water balance in a watershed. Temperature, radiation, wind speed, and actual vapor pressure are the major climate factors that influence actual evapotranspiration. Based on the Penman equation, the daily evaporation from a pan (Allen et al., 1998; Sun et al., 2010) can be expressed as

$$
\begin{aligned}
E_{\mathrm{pan}} & =\frac{\mathrm{ET}_{\mathrm{R}}+\mathrm{ET}_{\mathrm{A}}}{K_{\mathrm{p}}}, \quad \mathrm{ET}_{\mathrm{R}}=\frac{\Delta}{\Delta+\gamma} \frac{R_{\mathrm{n}}-G}{\lambda}, \\
\mathrm{ET}_{\mathrm{A}} & =\frac{\gamma}{\Delta+\gamma} f\left(U_{2}\right)\left(e_{\mathrm{s}}-e_{\mathrm{a}}\right)
\end{aligned}
$$

where $\mathrm{ET}_{\mathrm{R}}\left(\mathrm{mm} \mathrm{day}^{-1}\right)$ and $\mathrm{ET}_{\mathrm{A}}\left(\mathrm{mmday}^{-1}\right)$ are the daily reference evapotranspiration related to the radiation and aerodynamic terms, respectively; $K_{\mathrm{p}}$ (dimensionless) is the pan coefficient and is chosen as 0.67 (Xu et al.,

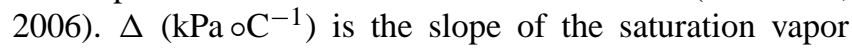
pressure curve; $\gamma(\mathrm{kPa})$ is the psychometric constant; $\lambda$ $\left(\mathrm{MJ} \mathrm{mm}^{-1}\right.$ ) represents the latent heat of evapotranspiration. $R_{\mathrm{n}}\left(\mathrm{MJ} \mathrm{m}^{-2}\right.$ day $\left.^{-1}\right)$ is the net radiation; $G\left(\mathrm{MJ} \mathrm{m}^{-2}\right.$ day $\left.^{-1}\right)$ is the soil heat flux density and assumed to be zero at the annual time step. $f\left(U_{2}\right)\left(\mathrm{mm} \mathrm{kPa}^{-1} \mathrm{day}^{-1}\right)$ is the function of wind speed (Sun et al., 2010); $U_{2}$ is the wind speed at $2 \mathrm{~m}$ height which is converted from the wind speed at $10 \mathrm{~m}$ height $\left(U_{10}\right) ; e_{\mathrm{S}}(\mathrm{kPa})$ and $e_{\mathrm{a}}(\mathrm{kPa})$ is the saturation vapor pressure and the air vapor pressure, respectively. The various items in Eq. (7) are calculated following Allen et al. (1998).

The contribution of different factors to the streamflow changes is quantified by differentiating Eqs. (6) and (7), i.e.

$$
\begin{aligned}
& \frac{\mathrm{d} R_{\mathrm{yr}}}{\mathrm{d} t}=\left[\frac{\mathrm{d}\left(\frac{a}{1000} \cdot P_{\mathrm{yr}}\right)}{\mathrm{d} t}-\frac{\mathrm{d}\left(\frac{b}{1000} \cdot E_{\mathrm{pan}, \mathrm{yr}}\right)}{\mathrm{d} t}+\frac{\mathrm{d}\left(c \cdot \Delta \mathrm{WL}_{\mathrm{yr}}\right)}{\mathrm{d} t}\right] \\
& \cdot \frac{A}{\mathrm{yd} \cdot 24 \cdot 3600}=\left\{\frac{\mathrm{d}\left(\frac{a}{1000} \cdot P_{\mathrm{yr}}\right)}{\mathrm{d} t}-\frac{\mathrm{d}\left[\frac{b}{1000} \cdot\left(\frac{\mathrm{ET}_{\mathrm{R}}+\mathrm{ET}_{\mathrm{A}}}{K_{\mathrm{P}}}\right)\right]}{\mathrm{d} t}\right. \\
& \left.++\frac{\mathrm{d}\left[c \cdot \Delta \mathrm{WL}_{\mathrm{yr}}\right]}{\mathrm{d} t}\right\} \cdot \frac{A}{\mathrm{yd} \cdot 24 \cdot 3600} \\
& =\underbrace{\frac{a}{1000} \frac{\mathrm{d} P_{\mathrm{yr}}}{\mathrm{d} t} \frac{A}{\mathrm{yd} \cdot 24 \cdot 3600}}_{P^{*}} \\
& +\underbrace{\left(-\frac{b}{1000 K_{\mathrm{p}}} \frac{\partial \mathrm{ET} \mathrm{R}_{\mathrm{p}, \mathrm{yr}}}{\partial R_{\mathrm{n}}} \frac{\mathrm{d} R_{\mathrm{n}}}{\mathrm{d} t} \frac{A}{\mathrm{yd} \cdot 24 \cdot 3600}\right)}_{R_{\mathrm{n}}^{*}}
\end{aligned}
$$

$$
\begin{aligned}
& +\underbrace{\left\{-\frac{b}{1000 K_{\mathrm{p}}} \frac{\partial \mathrm{ET}_{\mathrm{A}, \mathrm{yr}}}{\partial\left[f\left(U_{2}\right)_{\mathrm{yr}}\right]} \frac{\mathrm{d}\left[f\left(U_{2}\right)_{\mathrm{yr}}\right]}{\mathrm{d} U_{2, \mathrm{yr}}} \frac{\mathrm{d} U_{2, \mathrm{yr}}}{\mathrm{d} t} \frac{A}{\mathrm{yd} \cdot 24 \cdot 3600}\right\}}_{U^{*}} \\
& +\underbrace{\frac{b}{1000 K_{\mathrm{p}}} \frac{\partial \mathrm{ET}_{\mathrm{A}, \mathrm{yr}}}{\partial e_{\mathrm{a}, \mathrm{yr}}} \frac{\mathrm{d} e_{\mathrm{a}, \mathrm{yr}}}{\mathrm{d} t} \frac{A}{\mathrm{yd} \cdot 24 \cdot 3600}}_{e_{\mathrm{a}}^{*}} \\
& +\underbrace{\left\{-\frac{b}{1000 K_{\mathrm{p}}}\left[\left(\frac{\partial \mathrm{ET}_{\mathrm{R}, \mathrm{yr}}}{\partial \Delta}+\frac{\partial \mathrm{ET}_{\mathrm{A}, \mathrm{yr}}}{\partial \Delta}\right) \frac{\mathrm{d} \Delta}{\mathrm{d} T_{\text {ave, }, \mathrm{yr}}}+\frac{\partial \mathrm{ET}_{\mathrm{A}, \mathrm{yr}}}{\partial e_{\mathrm{S}, \mathrm{r}}} \frac{\mathrm{d} e_{\mathrm{S}, \mathrm{yr}}}{\left.\mathrm{d}_{\mathrm{ave}, \mathrm{r}}\right]}\right] \frac{\left.\mathrm{d} T_{\mathrm{ave}, \mathrm{yr}} \frac{A}{\mathrm{dd} \cdot 24 \cdot 3600}\right\}}{\mathrm{yd} \cdot 24 \cdot 3600}\right.}_{W^{*}}=P^{*} \underbrace{+R_{\mathrm{n}}^{*}+U^{*}+e_{\mathrm{a}}^{*}+T_{\mathrm{ave}}^{*}}_{E^{*}}+W^{*}
\end{aligned}
$$

where $P^{*}, E^{*}\left(R_{\mathrm{n}}^{*}, U^{*}, e_{\mathrm{a}}^{*}\right.$ and $\left.T_{\mathrm{ave}}^{*}\right)$, and $W^{*}$ represent the contribution of change in annual precipitation, evapotranspiration related to net radiation, wind speed, actual vapor pressure and mean temperature, and intra-annual variability of river level on the streamflow changes, respectively.

\subsubsection{Projected changes of precipitation and evapotranspiration, and their contributions to the future streamflow variations}

In the present study, we didn't utilize the complicated methods (e.g. statistical downscaling and dynamic downscaling) to process the datasets, instead we used a simple and efficient approach (named Delta method) to obtain the projected climate change which may occur in the study region. The Delta method was proposed by the United States Global Change Research Program (USGCRP) and has since been compared with other downscaling methods in the United States (Hay et al., 2000) and Yellow River Basin in China (Zhao and Xu, 2008). Recently, a number of scientists have utilized the same or similar method to evaluate the potential changes of streamflow or other environmental variables (Miller et al., 2003; Ju et al., 2007; Cramer et al., 2001).

The precipitation and evaporation simulated by AOGCMs (including $20 \mathrm{C} 3 \mathrm{M}$ and three emission scenarios) were extracted for an area $\left(110-120^{\circ} \mathrm{E}, 20-35^{\circ} \mathrm{N}\right)$ and were interpolated into the study region using the Spline Function method in the ArcGIS 9.2 platform. The areal means of the projected precipitation and evapotranspiration during 20612100 were calculated for different watersheds. To constrain the effects of single model biases on assessing the future changes of streamflow caused by climate change, precipitation and evapotranspiration during 2061-2100 can be calculated as follows:

$\Delta \operatorname{var}^{k}=\frac{1}{n} \sum_{i=1}^{n}\left(\frac{\operatorname{var}^{\mathrm{obs}}}{\operatorname{var}_{i}^{20 \mathrm{C} 3 \mathrm{M}}} \cdot \operatorname{var}_{i}^{k}-\operatorname{var}^{\mathrm{obs}}\right)$

where var denotes the mean of precipitation/ evapotranspiration; $\Delta \operatorname{var}^{k}$ represents the change of the mean of var during 2061-2100 projected by AOGCMs relative to the mean of 

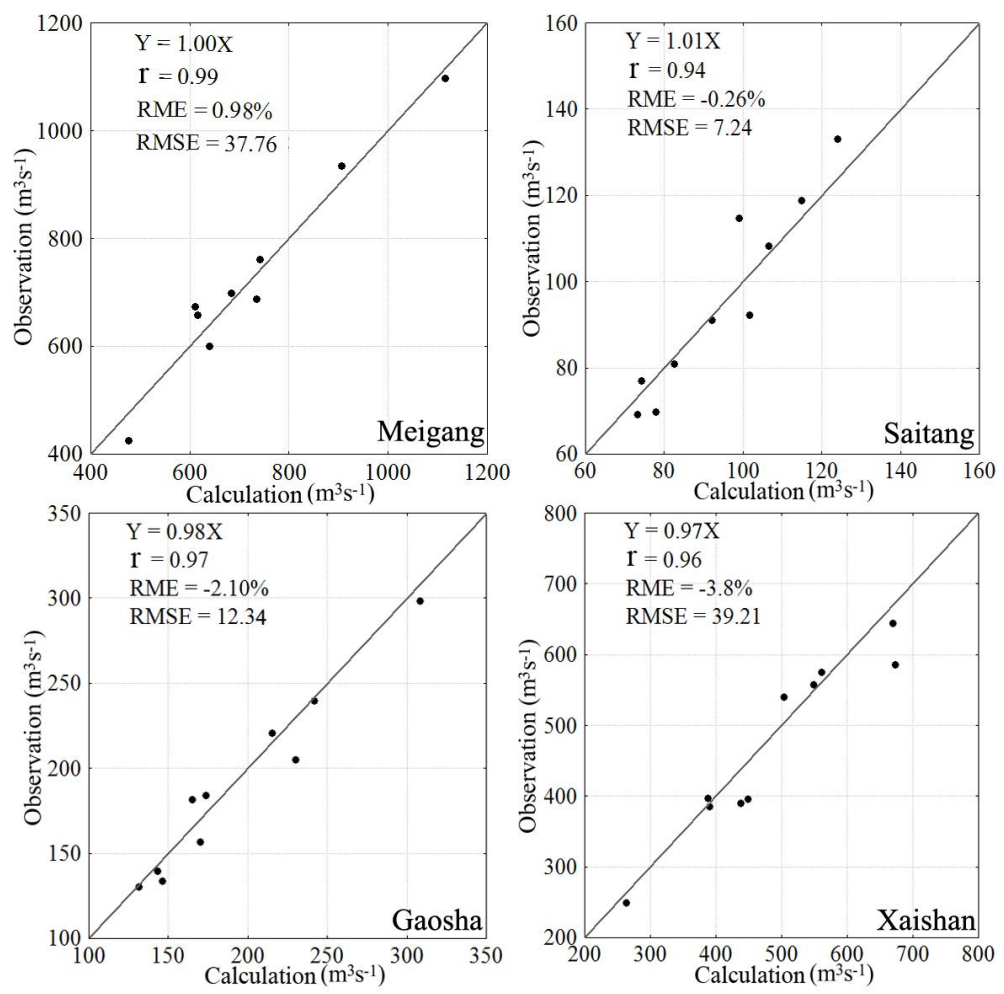

Fig. 3. Comparison of observed and estimated annual mean streamflow during the period from 1991-2000. The solid lines are the 1:1 lines.

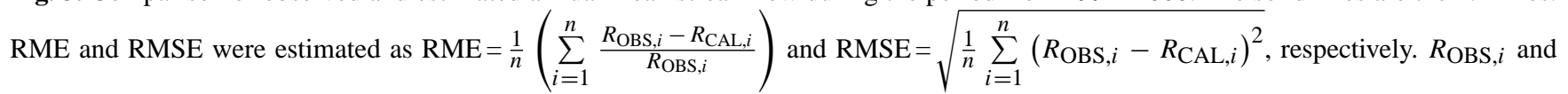
$R_{\mathrm{CAL}, i}$ are the observed and calculated streamflow values, $n=10$.

observation during 1961-2000; $k$ denotes the $k$-th future climate scenarios; $n$ is the number of AOGCMs under the $k$-th scenario; $\operatorname{var}_{i}^{k}$ is var during 2061-2100 projected by the $i$-th AOGCM under the $k$-th scenario; var ${ }^{\text {obs }}$ represents the mean

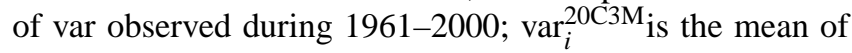
var projected by the $i$-th AOGCM under the contemporary emission.

Therefore, the future changes of streamflow relative to the observed mean during 1961-2000 caused by the changes in precipitation or evaporation $\left(\Delta R_{i}\right)$ are quantified as

$\Delta R_{i}=\frac{\frac{C}{D} \cdot \Delta \operatorname{var}^{k}}{R^{\text {obs }}} \cdot 100 \%$

where $\Delta R_{i}$ represents the percentage change caused by the single climate variables (precipitation or evapotranspiration); $R^{\mathrm{obs}}$ is the mean of observed streamflow from 1961-2000; $C$ denotes the coefficient $a$ for the precipitation term or $b$ for the evapotranspiration term; $D$ is 1 and $K_{\mathrm{p}}$ for precipitation and evapotranspiration, respectively.

\section{Results and analyses}

\subsection{Optimized parameters in the water balance equation}

Based on the least squares method, parameters $a, b$ and $c$ in Eq. (6) are optimized using the observed datasets during the period 1961-1990 and listed in Table 2. Evidently these parameters differ in different watersheds (Table 2), and their differences are evaluated in the following discussion section. Validation using the independent climate and streamflow observations during the period from 1991-2000 confirms that the calibrated water balance equation (Eq. 6) is able to capture the interannual variations of streamflow in different watersheds (Fig. 3). The calculated annual mean streamflow is in good agreement with the observation in each watershed, with $r$ (the correlation coefficient between the calculated and observed streamflows) above 0.94 at the $5 \%$ significance level, relative mean error (RME) in the range from -3.8 to $0.98 \%$, and root mean square error (RMSE) ranging from 7.24 to $39.21 \mathrm{~m}^{3} \mathrm{~s}^{-1}$. The estimated streamflow is slightly larger than the observation in Meigang watershed, but slightly smaller than observations in the other three watersheds. The validation demonstrates that the model 
Table 2. Parameters in Eq. (6) optimized for four watersheds in the study region.

\begin{tabular}{rcrrrr}
\hline & Parameters & Meigang & Saitang & Gaosha & Xiashan \\
\hline \multirow{2}{*}{$1961-1990$} & $a$ & $0.96^{* *}$ & $0.82^{* *}$ & $0.82^{* *}$ & $0.85^{* *}$ \\
& $b$ & $0.38^{* *}$ & $0.30^{* *}$ & $0.33^{* *}$ & $0.34^{* *}$ \\
& $c$ & $-0.15^{* *}$ & $-0.32^{* *}$ & $-0.19^{*}$ & $-0.11^{* *}$ \\
\hline \multirow{2}{*}{$1961-2000$} & $a$ & $0.98^{* *}$ & $0.84^{* *}$ & $0.79^{* *}$ & $0.82^{* *}$ \\
& $b$ & $0.40^{* *}$ & $0.32^{* *}$ & $0.29^{* *}$ & $0.32^{* *}$ \\
& $c$ & $-0.14^{* *}$ & $-0.30^{* *}$ & $-0.22^{* *}$ & $-0.12^{* *}$ \\
\hline
\end{tabular}

Note: ${ }^{*}$ and ${ }^{* *}$ denote that the value is statistically significant at the $5 \%$ and $1 \%$ level, respectively.

developed in this study is applicable to calculate streamflow from climate, pan evaporation and water level data at the watershed scale.

Table 2 lists the values of parameters $a, b$ and $c$ in Eq. (6) optimized using the observations for two periods during 1961-2000, and indicates that these parameters differ little between the two periods, and thus can be applied to project the future changes of streamflow under different climate scenarios. The optimized parameter values are used to investigate the influences of the different climate variables on the streamflow.

\subsection{Annual and seasonal variations of streamflow}

Figure 4 shows the measured monthly and annual streamflow averaged over the period from 1961-2000 for all the watersheds. Overall, the streamflow in each watershed increases from January, peaks in June and then decreases sharply from July, following the seasonal patterns of precipitation (Fig. 2b). The 40-yr means of annual streamflow are $578.35 \mathrm{~m}^{3} \mathrm{~s}^{-1}, 84.08 \mathrm{~m}^{3} \mathrm{~s}^{-1}, \quad 158.71 \mathrm{~m}^{3} \mathrm{~s}^{-1}$ and $440.01 \mathrm{~m}^{3} \mathrm{~s}^{-1}$ for Meigang, Saitang, Gaosha, and Xiashan watersheds, respectively. The large differences in their magnitudes of the streamflow are mainly due to their differences in the scales.

The streamflow shows distinct interannual and decadal variations in all the watersheds (Fig. 5). The decadal means of streamflow are higher in 1990s than in other periods for all the watersheds (Table 3). Meigang and Saitang watersheds have the lowest streamflow in $1980 \mathrm{~s}\left(535.65 \mathrm{~m}^{3} \mathrm{~s}^{-1}\right)$ and $1970 \mathrm{~s}\left(72.98 \mathrm{~m}^{3} \mathrm{~s}^{-1}\right)$, respectively, while the lowest streamflow appears in 1960s for Gaosha and Xiashan watersheds. The streamflow generally shows overall increasing trends during the study period of $40 \mathrm{yr}$ in all the four watersheds. It increases statistically significantly at the $5 \%$ level in the Meigang (4.78 $\left.\mathrm{m}^{3} \mathrm{~s}^{-1} \mathrm{yr}^{-1}\right)$ and Gaosha $\left(1.29 \mathrm{~m}^{3} \mathrm{~s}^{-1} \mathrm{yr}^{-1}\right)$ watersheds. It also increases in Saitang and Xiashan watersheds, but with a small magnitude.

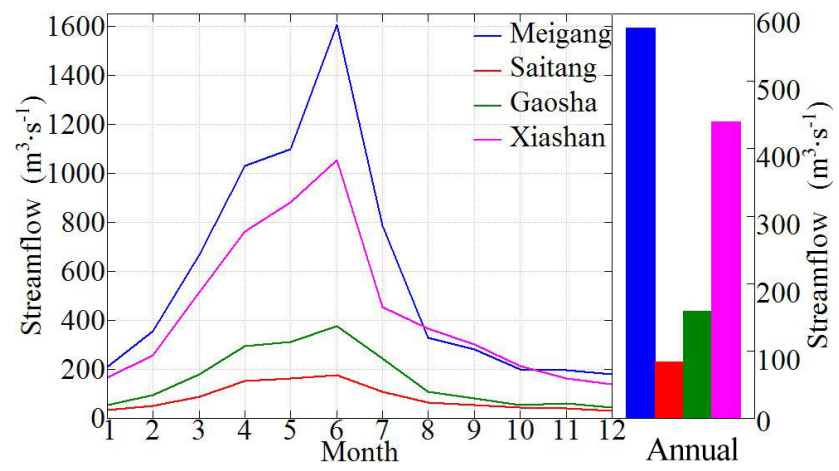

Fig. 4. Monthly and annual streamflow averaged over the period 1961-2000.

\subsection{Temporal trends of precipitation, pan evaporation and intra-annual changes of river level}

Figure 6 shows the temporal trends of annual precipitation, pan evaporation and intra-annual change of river levels in the four watersheds during 1961-2000. Annual precipitation increases in each watershed. In Meigang and Gaosha watersheds, it has a statistically significant increasing trend of $8.05 \mathrm{~mm} \mathrm{yr}^{-1}$ and $8.65 \mathrm{~mm} \mathrm{yr}^{-1}$ at the $5 \%$ level, respectively. Pan evaporation declines significantly $(p<0.05)$ in all the watersheds, with Saitang having the biggest decline $\left(-5.86 \mathrm{~mm} \mathrm{yr}^{-1}\right)$, followed by Xiashan $\left(-5.31 \mathrm{~mm} \mathrm{yr}^{-1}\right)$. Intra-annual change of river level decreases slowly but statistically insignificantly.

Seen from Eq. (7), it is known that the changes in the total net radiation, actual vapor pressure, mean temperature, and $2 \mathrm{~m}$ wind speed can impact the evapotranspiration obviously, further causing the streamflow to change. Hence, the rates of their changes during 1961-2000 are listed in Table 4. Annual total net radiation and wind speed decrease significantly, with a rate of change ranging from $-4.41 \mathrm{MJ} \mathrm{m}^{-2} \mathrm{yr}^{-1}$ to $-10.21 \mathrm{MJ} \mathrm{m}^{-2} \mathrm{yr}^{-1}$ and from $-8.00 \times 10^{-3} \mathrm{~m} \mathrm{~s}^{-1} \mathrm{yr}^{-1}$ to $-1.48 \times 10^{-2} \mathrm{~m} \mathrm{~s}^{-1} \mathrm{yr}^{-1}$ among the different watersheds, respectively. Actual vapor pressure shows small and insignificant increasing trends. Annual mean temperature marginally decreases in Saitang watershed $\left(-4.40 \times 10^{-3}{ }^{\circ} \mathrm{C} \mathrm{yr}^{-1}\right)$, while it increases at very small rates in the other three watersheds.

\subsection{Contributions of different climate factors to the changes of streamflow}

The contributions of different factors to streamflow changes are quantified using Eq. (8) and shown in Table 5. Increases of precipitation, decreases of evapotranspiration and intra-annual variation of river level lead to increases in streamflow. Net radiation, actual vapor pressure, temperature and wind speed indirectly impact on streamflow through their roles in evapotranspiration. If evapotranspiration increases with net radiation and wind speed, streamflow will 

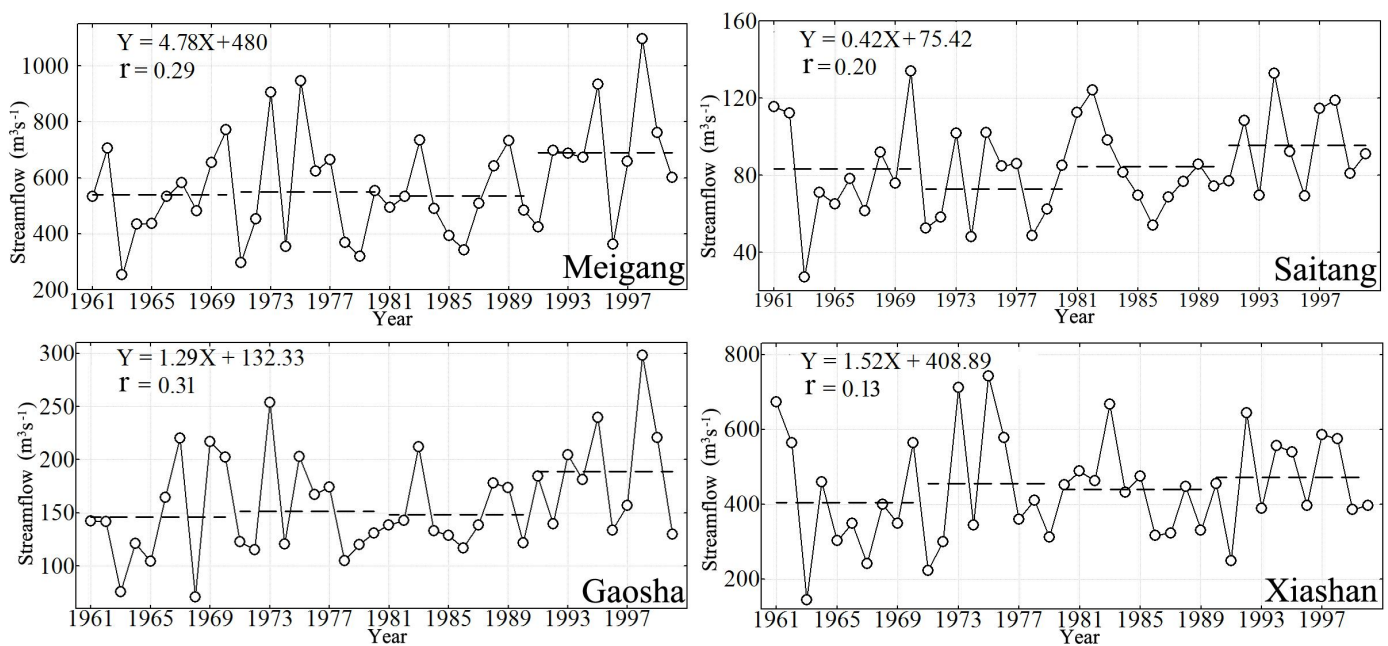

Fig. 5. Annual mean streamflow during the period 1961-2000.
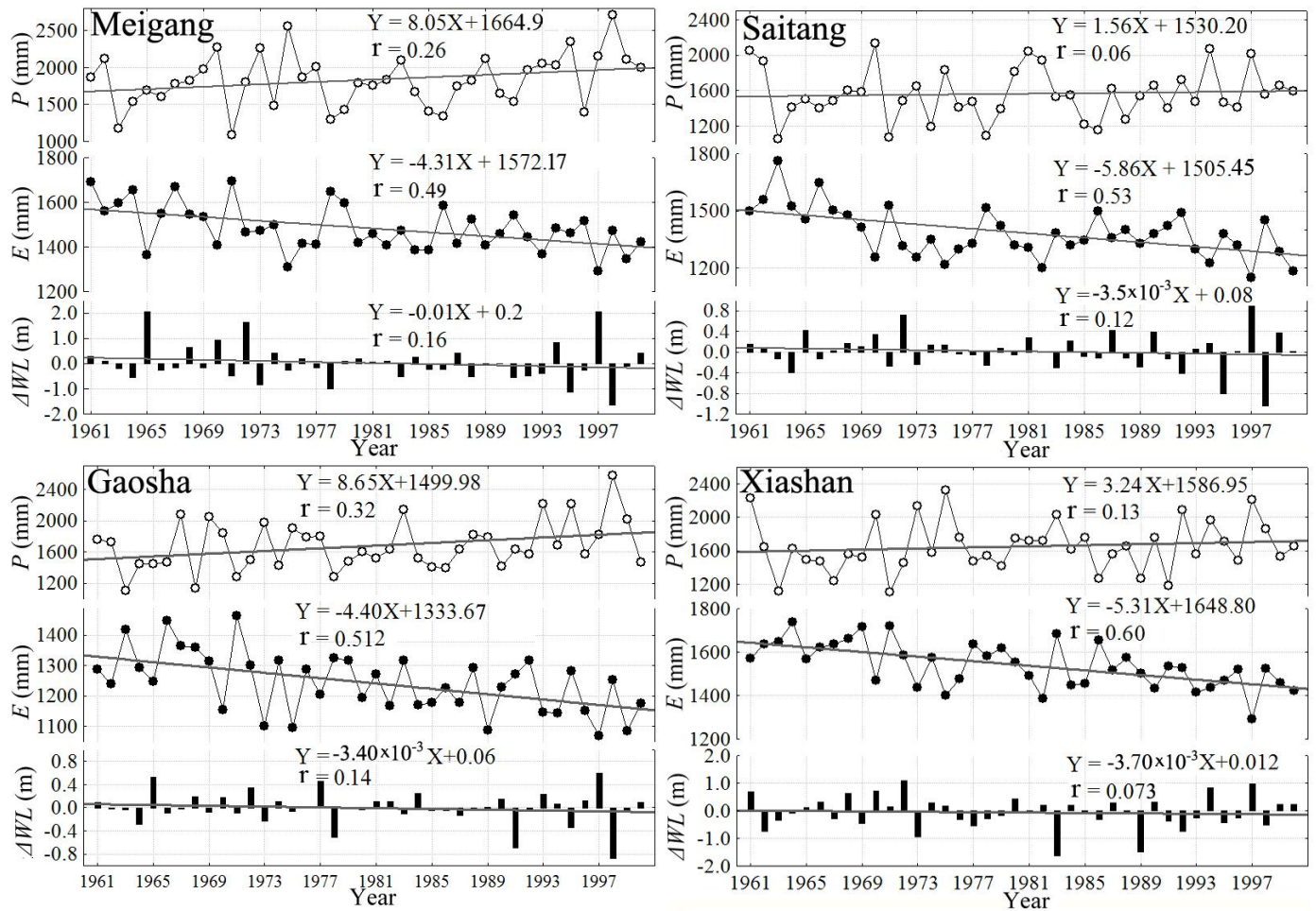

Fig. 6. Annual means of precipitation, pan evaporation and intra-annual variations of river level during 1961-2000.

consequently have a decreasing trend. Evapotranspiration is positively correlated with temperature, and thus it increases with temperature. The streamflow consequently decreases (and vice versa) with temperature. In contrast, the relationship between evaporation and actual vapor pressure are opposite. Decreases of evapotranspiration caused by increases in actual vapor pressure lead to an increase in streamflow, and vice versa. In Meigang, Gaosha, and Xiashan watersheds, precipitation has the biggest influence on streamflow, followed by evapotranspiration and then intra-annual variation of river level $\left(P^{*}>E^{*}>W^{*}\right.$, Table 5). Hence, the increase in precipitation contributes most to the streamflow increment. These are consistent with the previous conclusions by Zhao et al. (2009) that precipitation is the major determinant of streamflow in Poyang Lake Basin. In Saitang watershed, precipitation increases marginally while actual evapotranspiration decreases significantly, caused by decreasing net radiation and wind speed. The decrease in actual 
Table 3. Decadal variations of streamflow for the four watersheds.

\begin{tabular}{lrrrrr}
\hline & $\begin{array}{r}1961-1970 \\
\left(\mathrm{~m}^{3} \mathrm{~s}^{-1}\right)\end{array}$ & $\begin{array}{r}1971-1980 \\
\left(\mathrm{~m}^{3} \mathrm{~s}^{-1}\right)\end{array}$ & $\begin{array}{r}1981-1990 \\
\left(\mathrm{~m}^{3} \mathrm{~s}^{-1}\right)\end{array}$ & $\begin{array}{r}1991-2000 \\
\left(\mathrm{~m}^{3} \mathrm{~s}^{-1}\right)\end{array}$ & $\begin{array}{r}1961-2000 \\
\left(\mathrm{~m}^{3} \mathrm{~s}^{-1}\right)\end{array}$ \\
\hline Meigang & 538.72 & 549.05 & 535.65 & 689.97 & 578.35 \\
Saitang & 83.32 & 72.98 & 84.54 & 95.48 & 84.08 \\
Gaosha & 146.06 & 151.38 & 148.49 & 188.93 & 158.71 \\
Xiashan & 404.58 & 443.46 & 439.97 & 472.04 & 440.01 \\
\hline
\end{tabular}

Table 4. Changes of annual total net radiation, mean actual vapor pressure, mean temperature, and mean $2 \mathrm{~m}$ wind speed for the period of 1961-2000.

\begin{tabular}{llcrc}
\hline & \multicolumn{4}{c}{ Climate variability } \\
\cline { 2 - 5 } & $\begin{array}{l}\mathrm{d} R_{\mathrm{n}} / \mathrm{d} t \\
\left(\mathrm{MJ} \mathrm{m}^{-2} \mathrm{yr}^{-1}\right)\end{array}$ & $\begin{array}{c}\mathrm{d} e a / \mathrm{d} t \\
\left(\mathrm{kPa} \mathrm{yr}^{-1}\right)\end{array}$ & $\begin{array}{r}\mathrm{d} T_{\mathrm{ave}} / \mathrm{d} t \\
\left({ }^{\circ} \mathrm{yr}^{-1}\right)\end{array}$ & $\begin{array}{c}\mathrm{d} U / \mathrm{d} t \\
\left(\mathrm{~m} \mathrm{~s}^{-1} \mathrm{yr}^{-1}\right)\end{array}$ \\
\hline Meigang & $-9.03^{* *}$ & $-5.00 \times 10^{-3}$ & $3.90 \times 10^{-3}$ & $-9.60 \times 10^{-3 * *}$ \\
Saitang & $-10.21^{* *}$ & $-1.00 \times 10^{-4}$ & $-4.40 \times 10^{-3}$ & $-1.43 \times 10^{-2 * *}$ \\
Gaosha & $-4.41^{*}$ & $-6.00 \times 10^{-5}$ & $2.60 \times 10^{-3}$ & $-8.00 \times 10^{-3 * *}$ \\
Xiashan & $-9.26^{* *}$ & $-8.00 \times 10^{-4}$ & $1.70 \times 10^{-3}$ & $-1.48 \times 10^{-2 * *}$ \\
\hline
\end{tabular}

Note: ${ }^{*}$ and ${ }^{* *}$ represent that the value is statistically signifiant at the $5 \%$ and $1 \%$ level, respectively.

Table 5. The variations of streamflow caused by the changes of precipitation, evapotranspiration and intra-annual river levels (units: $\left.\mathrm{m}^{3} \mathrm{~s}^{-1} \mathrm{yr}^{-1}\right)$.

\begin{tabular}{lccccccc}
\hline & $P^{*}$ & $E^{*}$ & \multicolumn{3}{c}{$\begin{array}{c}\text { Effects of climatic factors on streamflow through } \\
\text { evapotranspiration processes }\end{array}$} & $W^{*}$ \\
\cline { 3 - 7 } & & & & \multicolumn{5}{c}{$R_{\mathrm{n}}^{*}$} & $e a^{*}$ & $T_{\text {ave }}^{*}$ & $U^{*}$ & \\
\hline Meigang & 3.79 & 0.82 & 0.59 & -0.12 & -0.20 & 0.51 & 0.68 \\
Saitang & 0.13 & 0.19 & 0.09 & -0.004 & 0.05 & 0.06 & 0.10 \\
Gaosha & 1.12 & 0.21 & 0.05 & -0.003 & -0.01 & 0.10 & 0.12 \\
Xiashan & 1.34 & 0.86 & 0.66 & -0.16 & -0.06 & 0.68 & 0.22 \\
\hline
\end{tabular}

evapotranspiration acts as the biggest contributor to the increase in streamflow $\left(0.19 \mathrm{~m}^{3} \mathrm{~s}^{-1} \mathrm{yr}^{-1}\right)$. The intra-annual variation of river level plays less of an important role in determining streamflow than precipitation and evapotranspiration in all of the watersheds.

\subsection{Variations of streamflow under three future emission scenarios}

Using the Eq. (9), Table 6 lists the changes of projected mean precipitation and evapotranspiration during 2061-2100 under three scenarios of greenhouse gases emission relative to the mean precipitation/evapotranspiration observed during 1961-2000. Multi-model ensemble means of the projected precipitation and evapotranspiration by the different AOGCMs are used to generate their integrated time series, and both of them exhibit considerable differences. For all of the four watersheds, precipitation and evapotranspiration are projected to increase under the three future climate scenarios, except for the evapotranspiration at Xiashan watershed under SRESA2. In addition, the increases in the precipitation as well as evapotranspiration under the scenario of SRESA2 will be the smallest, while evapotranspiration at Xiashan watershed will possibly decrease by $0.28 \%$ under this scenario.

Therefore, the future change of streamflow $\left(\Delta R_{i}\right)$ relative to the observed mean during 1961-2000 due to the changes in precipitation or evaporation is calculated with Eq. (10). Figure 7 depicts the calculated $\Delta R_{i}$ values for different climate change scenarios and watersheds. For all the watersheds, the projected precipitation changes will cause streamflow to increase under the three future climate scenarios. Under the SRESA1B scenario, the largest precipitationinduced increase of streamflow will be in the Meigang watershed $(+7.16 \%)$ and Xiashan watershed $(+6.04 \%)$. Under the SRESB1 scenario, the largest precipitation-induced increase of streamflow will be under the SRESB1 scenario in Saitang watershed $(+9.13 \%)$ and Gaosha watershed $(+6.93 \%)$. However, for the three future climate scenarios, evapotranspiration changes will cause streamflow to decrease in all 

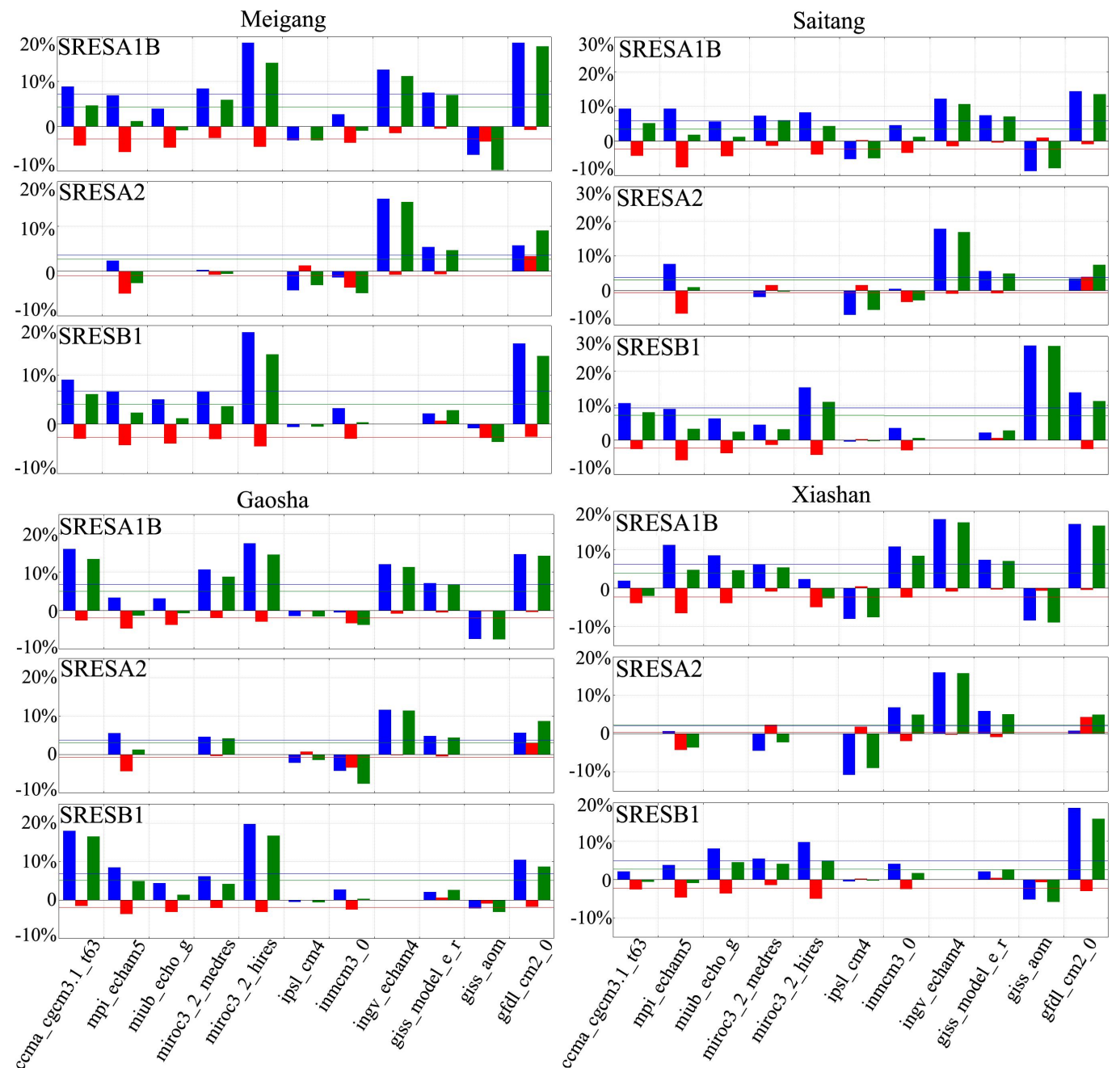

Fig. 7. Changes of streamflow in four watersheds caused by changes of precipitation and evapotranspiration projected under different greenhouse gasses emission scenarios. Blue, red, and green bars represent changes of streamflow caused by changes of precipitation, evapotranspiration, and both precipitation and evapotranspiration projected by individual AOGCMs, respectively. Blue, red, and green lines represent the averaged changes of streamflow caused by changes of precipitation, evapotranspiration, and both precipitation and evapotranspiration, respectively.

watersheds, except for Xiashan under the SRESA2 scenario, which shows an increase in streamflow by $0.16 \%$. The largest decrease of streamflow caused by evapotranspiration appears under the scenario of SRESA1B for Meigang $(-2.85 \%)$, Saitang $(-2.42 \%)$, and Gaosha $(-1.89 \%)$ watersheds. Evapotranspiration-induced decrease of streamflow will be the largest under the scenario of SRESB1 in the Xiashan watershed $(-2.23 \%)$. The changes of streamflow will differ among watersheds for the same future climate scenario.

With the assumption that the future changes in soil water storage is ignorable, the simultaneous changes in both averaged precipitation and evapotranspiration will cause streamflow to increase in all of the watersheds (Green bars in Fig. 7). The changes in precipitation and evapotranspiration together will result in the largest increase in Meigang $(+4.31 \%$ and Xiashan $(+3.84 \%)$ watersheds under the SRESA1B scenario, but in Saitang $(+6.87 \%)$ and Gaosha $(+5.15 \%)$ under the SRESB1 scenario.

\section{Discussions}

\subsection{Causes of differences of parameters $a, b$, and $c$ among the four watersheds}

Parameter $a$ represents the ratio of throughfall to total precipitation above canopy, while $1-a$ is relative to the effectiveness of the interception capacity of vegetation (e.g. canopy interception and stem interception) and the intercepted water evaporation. Wen and Liu (1995) quantitatively analyzed 
Table 6. Percentage changes of precipitation and evapotranspiration projected under three greenhouse gases emission scenarios.

\begin{tabular}{|c|c|c|c|c|c|}
\hline Variable & Watershed & & SRESA1B & SRESA2 & SRESB1 \\
\hline \multirow[t]{7}{*}{ Precipitation } & Meigang & $\begin{array}{l}\text { Range } \\
\text { Average }\end{array}$ & $\begin{array}{c}-2.07 \sim 12.46 \\
4.78\end{array}$ & $\begin{array}{c}-2.86 \sim 10.79 \\
2.30\end{array}$ & $\begin{array}{c}-0.50 \sim 12.43 \\
4.42\end{array}$ \\
\hline & \multirow[t]{2}{*}{ Saitang } & Range & $-5.69 \sim 9.42$ & $-4.60 \sim 11.69$ & $-0.31 \sim 17.90$ \\
\hline & & Average & 3.83 & 2.44 & 6.00 \\
\hline & \multirow[t]{2}{*}{ Gaosha } & Range & $-5.36 \sim 12.66$ & $-3.1 \sim 8.44$ & $-1.56 \sim 14.39$ \\
\hline & & Average & 4.95 & 2.67 & 5.04 \\
\hline & \multirow[t]{2}{*}{ Xiashan } & Range & $-5.36 \sim 11.47$ & $-6.85 \sim 10.20$ & $-3.32 \sim 12.01$ \\
\hline & & Average & 3.88 & 1.36 & 3.11 \\
\hline \multirow[t]{8}{*}{ Evapotranspiration } & \multirow[t]{2}{*}{ Meigang } & Range & $-0.03 \sim 11.61$ & $-2.44 \sim 10.11$ & $-1.39 \sim 8.58$ \\
\hline & & Average & 5.8 & 1.81 & 5.27 \\
\hline & \multirow[t]{2}{*}{ Saitang } & Range & $-0.37 \sim 14.52$ & $-7.56 \sim 12.85$ & $-1.11 \sim 11.24$ \\
\hline & & Average & 4.67 & 1.30 & 4.36 \\
\hline & \multirow[t]{2}{*}{ Gaosha } & Range & $0.26 \sim 12.34$ & $-7.99 \sim 11.50$ & $-1.52 \sim 9.62$ \\
\hline & & Average & 5.02 & 1.91 & 4.75 \\
\hline & \multirow[t]{2}{*}{ Xiashan } & Range & $-0.76 \sim 11.55$ & $-7.58 \sim 7.48$ & $-0.73 \sim 8.68$ \\
\hline & & Average & 3.91 & -0.28 & 3.96 \\
\hline \multirow[t]{8}{*}{ Streamflow } & \multirow[t]{2}{*}{ Meigang } & Range & $-9.73 \sim 17.87$ & $-4.92 \sim 15.40$ & $-3.52 \sim 14.18$ \\
\hline & & Average & 4.31 & 2.56 & 4.03 \\
\hline & \multirow[t]{2}{*}{ Saitang } & Range & $-7.80 \sim 13.46$ & $-5.55 \sim 16.87$ & $-0.33 \sim 27.14$ \\
\hline & & Average & 3.41 & 3.05 & 6.87 \\
\hline & \multirow[t]{2}{*}{ Gaosha } & Range & $-7.48 \sim 14.55$ & $-7.64 \sim 11.43$ & $-3.07 \sim 16.72$ \\
\hline & & Average & 4.93 & 2.96 & 5.15 \\
\hline & \multirow[t]{2}{*}{ Xiashan } & Range & $-8.95 \sim 17.06$ & $-8.89 \sim 15.72$ & $-5.78 \sim 15.78$ \\
\hline & & Average & 3.84 & 2.28 & 2.61 \\
\hline
\end{tabular}

the characteristics of rainfall interception of dormaint forest ecosystems in China, and found that the interception coefficient $(1-a)$ differed considerably in various forest ecosystems and the mean values usually ranged from 11.4 to $36.5 \%$. Crockford and Richardson (2000) and Fan et al. (2007) pointed out that a number of factors could influence the canopy interception coefficient, such as rainfall characters (quantity, intensity and duration), wind speed, environment, vegetation types and their canopy density. Generally, the interception coefficient is larger if the canopy is denser and the wind is weaker. There are no big differences in monthly rainfall among all the four watersheds (Fig. 2). Figure 8 shows the monthly and annual means of leaf area index (LAI) derived from the SPOT VGT-NDVI datasets during 1999-2000, and 10m wind speed from 1961-2000 for each watershed, respectively. For Gaosha and Saitang watersheds, the seasonal variations of rainfall and LAI are asynchronous. Among all the four watersheds, Gaosha watershed has the larger annual mean LAI and weakest wind speed, resulting in the smallest value of $a(0.79)$ and highest interception coefficient $(1-a=0.21)$ for the period 1961-2001. Meigang watershed has the highest wind speed and the second lowest LAI (only slightly higher than LAI in Xiashan watershed). It has the most precipitation in the months of March to June (Fig. 8) when its LAI is low owing to the high percentage $(22.60 \%)$ of farmland in this watershed with two rotations of rice cultivation. The early rotation of rice is planted in the middle of April and harvest in late July. During the months from January to June, wind is much stronger here than in the other watersheds. The value of parameter $a$ is highest among the four watersheds. The interception coefficient of this watershed during the period 1961-2000 is only 0.02.

The actual evapotranspiration of a watershed can be estimated based on Eq. (3) using $20 \mathrm{~cm}$ caliber pan evaporation observations. The estimated multi-year mean values of actual evapotranspiration differ little with the observations for all of the watersheds (Table 7), indicating that the parameter $b$ is reasonable for simulating the actual evapotranspiration in gereral. Further analysis of the differences between the estimated actual evapotranspiration and the observations among the four watersheds shows some differencs in Xiashan $(-44.17 \mathrm{~mm})$ and Meigang $(46.22 \mathrm{~mm})$. It is known that variation in the actual evapotranspiration can be influenced by water sources (e.g. precipitation and soil moisture), the radiation and aerodynamic drving factors (e.g. radiation, wind speed, temperature and atomosphere water vapor), and vegetation (e.g. vegetation types and physiological structure). Poyang Lake Basin belongs to a typical humid climate zone with annual precipitation more than $1600 \mathrm{~mm}$. When there is enough water for evaporation and transpiration, the evapotranspiration processes are mainly determined by the radiation and aerodynamic driving factors, and vegetation. To 

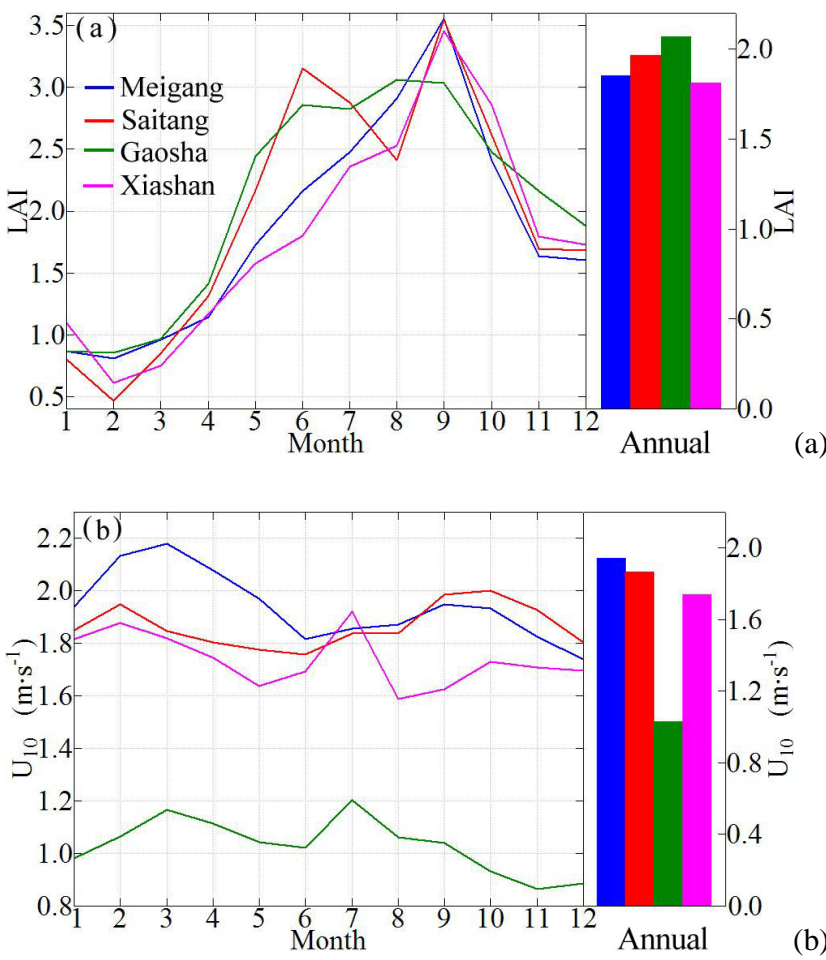

(b)

Fig. 8. Seasonal variations and annual means of LAI (19992000) (a) and $10 \mathrm{~m}$ wind speed (1961-2000) (b) in the four watersheds in the study region.

uncover the estimation versus observation difference, the averaged values of the radiation and aerodynamic terms are analyzed using Eq. (7) and the major driving factors of reference evapotranspiration are listed in Table 8. For Gaosha, evapotranspiration is the smallest because of the least values of $\mathrm{ET}_{\mathrm{R}}$ and $\mathrm{ET}_{\mathrm{A}}$, which are caused by the lowest $R_{\mathrm{n}}$ and $U_{2}$, respectively. Meigang and Xiashan have the highest evaporation values owing to the higher values of $R_{\mathrm{n}}, U_{2}$ and $\left(e_{\mathrm{S}}-e_{\mathrm{a}}\right)$. However, smaller $\mathrm{ET}_{\mathrm{R}}$ and $\mathrm{ET}_{\mathrm{A}}$ in Saitang result in lower evapotranspiration. In general, the differences in the mean evapotranspiration values for the four watersheds are mainly determined by $R_{\mathrm{n}}, U_{2}$ and $\left(e_{\mathrm{s}}-e_{\mathrm{a}}\right)$.

Because it is difficult to obtain reliable and long-term soil water storage data, we utilized Eq. (5) to evaluate the parameters $c$. The 40-yr means of intra-annual changes of river levels in the four watersheds ranged from $-6.25 \times 10^{-2} \mathrm{~m}$ to $1.19 \times 10^{-2} \mathrm{~m}$, which is consistent with the hypothesis that the long-term average of intra-annual variation of river level is small. This suggests that Eq. (6) can be used to calculate streamflow according to measurements of precipitation, pan evaporation, and river levels. Additionally, the effects of the soil water storage on streamflow will be investigated in our future work with hydrological models.
Table 7. Comparsions of multi-year mean values of actual evapotranspiration with the observations.

\begin{tabular}{lrrrr}
\hline & $\begin{array}{r}\text { Meigang } \\
(\mathrm{mm})\end{array}$ & $\begin{array}{r}\text { Saitang } \\
(\mathrm{mm})\end{array}$ & $\begin{array}{r}\text { Gaosha } \\
(\mathrm{mm})\end{array}$ & $\begin{array}{r}\text { Xiashan } \\
(\mathrm{mm})\end{array}$ \\
\hline Estimated (1961-2000) & 585.83 & 546.93 & 490.91 & 607.97 \\
Observed (1983-2006) & 539.61 & 534.15 & 518.32 & 652.14 \\
Difference & 46.22 & 12.78 & -27.41 & -44.17 \\
estimated-observed & & & & \\
\hline
\end{tabular}

\subsection{Potential impacts of other factors on streamflow}

Long-term changes in streamflow depend on the balance of precipitation and evapotranspiration. The latter is mainly driven by climate factors and vegetation characteristics, such as radiation, wind, actual vapor pressure, temperature, and vegetation types and density. However, previous researchers mainly focused on the response of streamflow to precipitation, temperature and land cover changes. The influences of other climate factors (e.g. radiation, wind and actual vapor pressure) on evapotranspiration have received less attention. In this study, we find that the effect of temperature on the streamflow (seen from Table 5) is limited compared to other climate variables (e.g. radiation and wind) in the four watersheds. Because of the complementation between evapotranspiration and runoff from water balance equation, the contribution of temperature to evapotranspiration is also limited, which is in agreement with the previous findings by other researchers (Roderick and Farquhar, 2002, 2004, 2005; Roderick et al., 2007; Sun et al., 2010). The contribution of radiation and wind should be taken into account in investigating the driving factors of streamflow changes. On the other hand, the observed streamflow trends $(\mathrm{d} R / \mathrm{d} t)$ can not be exactly explained by the total contribution from precipitation, evapotranspiration and intra-annual river level. This is mainly due to exclusion of the effects of human activities (e.g. agricultural irrigation, water conservation facilities and land-use change; Guo et al., 2008), and acclimation of plant physiology (e.g. stomatal) and structures (e.g. LAI) to elevated atmospheric $\mathrm{CO}_{2}$ concentrations (Gedney et al., 2006; Piao et al., 2007; Field et al., 1995; Cowling and Field, 2003).

Land-use change and establishments of water conservation facilities can influence the interception of vegetation and the ability of soil infiltration, and thus play important roles on hydrological regimes, and mechanisms of runoff yield and concentration. Some studies suggested that land-use changes has impacted the water cycle and would continue to do so in the next century (Costa and Foley, 1997; Jackson et al., 2005; Foley et al., 2005). Since the late 1960s, Poyang Lake Basin has been used for high head hydropower production and navigation. By the end of 2005, there were 315 hydropower stations operating in Jiangxi Province, which were above $1000 \mathrm{KW}$ (Zhao et al., 2009). On the other hand, the land-use change could also influence the annual and seasonal 
Table 8. Annual means of the radiation and aerodynamic terms, and the driving factors of the reference evapotranspiration during the period of 1961-2000.

\begin{tabular}{lccccc}
\hline & $\begin{array}{c}\mathrm{ET}_{\mathrm{R}} \\
(\mathrm{mm})\end{array}$ & $\begin{array}{c}R_{\mathrm{n}} \\
\left(\mathrm{MJ} \mathrm{m}^{2}\right)\end{array}$ & $\begin{array}{c}\mathrm{ET}_{\mathrm{A}} \\
(\mathrm{mm})\end{array}$ & $\begin{array}{c}U_{2} \\
\left(\mathrm{~m} \mathrm{~s}^{-1}\right)\end{array}$ & $\begin{array}{c}e_{\mathrm{S}}-e_{\mathrm{a}} \\
(\mathrm{kPa})\end{array}$ \\
\hline Meigang & 868.19 & 2010.21 & 615.67 & 1.38 & 0.071 \\
Saitang & 824.11 & 1969.91 & 561.22 & 1.23 & 0.067 \\
Gaosha & 770.82 & 1800.39 & 472.65 & 0.74 & 0.070 \\
Xiashan & 928.78 & 2070.34 & 611.16 & 1.26 & 0.074 \\
\hline
\end{tabular}

flows, although the climate effect is the dominant factor in determining annual streamflow (Guo et al., 2008). After the Chinese economic reform, the hydropower plant construction, urbanization and population increment, etc. would definitely influence the catchments attributes and the water utilization. In order to estimate the contributions of climate changes to the streamflow more accurately, we will consider the effects of vegetation growth feedback, land-use change and human activities on the streamflow in the future.

\section{Conclusions}

Based on the historical streamflow data of the four gauge stations in Poyang Lake Basin, it is shown that the annual streamflow in the four watersheds exhibits different increasing trends during 1961-2000. The streamflows in the Meigang and Gaosha watersheds increase by $4.80 \mathrm{~m}^{3} \mathrm{~s}^{-1} \mathrm{yr}^{-1}$ and $1.29 \mathrm{~m}^{3} \mathrm{~s}^{-1} \mathrm{yr}^{-1}$, respectively, and these increasing trends are statistically significant at the $5 \%$ level.

Climate variability induces considerable changes in the terrestrial water cycle in the Poyang Lake Basin. Increased precipitation is the biggest contributor to the streamflow increment in Meigang, Gaosha, and Xiashan watershed, while decreased evapotranspiration is the main reason of streamflow increment in Saitang watershed. Changes due to the intra-annual changes of river levels are relatively small and can be ignored. Radiation, wind speed, actual vapor pressure and temperature can influence evapotranspiration processes, consequently leading streamflow to change indirectly. The sign of the contribution (positive or negative) to the streamflow depends on the relationships among climatic variables, evapotranspiration and streamflow. In this study, radiation and wind reduction cause the streamflow to increase for each watershed, and thus the decreasing actual vapor pressure results in a decrease in streamflow. Streamflow decreases with the increase in mean temperature in Meigang, Gaosha and Xiashan watersheds, but increases slightly in Saitang watershed due to the decreases in mean temperature. Comparing the contribution of the different climate variables to evapotranspiration and streamflow trends in the four watersheds, radiation and wind have the larger contribution than the actual vapor pressure and mean temperature.

The future climates projected by different AOGCMs under SRESA1B, SRESA2 and SRESB1 scenarios are used to assess the future changes of streamflow in the study region. Ignoring the changes of soil water storage, with an increase in precipitation and evaporation (except for the SRESB1 scenario in the Xiashan watershed), the streamflow shows an upward trend. Furthermore, the most significant increase of the streamflow is found at Meigang $(+4.31 \%)$ and Xiashan $(+3.84 \%)$ under the SRESA1B scenario. However, the increases in the streamflow at Saitang $(+6.87 \%)$ and Gaosha $(+5.15 \%)$ are projected under the SRESB1 scenario.

Acknowledgements. This work was jointly supported by the National Basic Research Program of China (Grant No. 2011CB952000) and the National Natural Science Foundation of China (Grant No. 40775061 \& Grant No. 41075082). The authors would like to thank those who provided the data for this research and the two anonymous reviewers for their helpful suggestions to improve the paper. Thanks also go to Liming Zhou (SUNY, Albany) and Bob Alex Ogwang for their careful review of the language and kindly help in improving the English.

Edited by: C. de Michele

\section{References}

Allen, R. G., Pereira, L. S., Raes, D., Smith, M.: Crop evapotranspiration-guidelines for computing crop water requirements-FAO Irrigation and Drainage Paper 56, ISBN $92-$ 5-104219-5, FAO, 1998.

Andréasson, J., Bergström, S. B., Carlsson, B., Graham, L. P., Lindström, G.: Hydrological change-climate change impact simulations for Sweden, Ambio, 33, 228-234, 2004.

Chen, H., Guo, S., Xu, C., Singh, V. P.: Historical temporal trends of hydro-climatic variables and runoff response to climate variability and their relevance in water resource management in the Hanjiang Basin, J. Hydrol., 344, 171-184, 2007.

Christensen, N. S. and Lettenmaier, D. P.: A multimodel ensemble approach to assessment of climate change impacts on the hydrology and water resources of the Colorado River Basin, Hydrol. Earth Syst. Sci., 11, 1417-1434, doi:10.5194/hess-11-14172007, 2007.

Costa, M. H. and Foley, J. A.: Water balance of the Amazon Basin: Dependence on vegetation cover and canopy conductance, J. Geophys. Res., 102, 23973-23989, 1997.

Cowling, S. A,. and Field, C. B.: Environmental control of leaf area production: Implications for vegetation and land-surface modeling, Global Biogeochem. Cy., 17, 1007, doi:10.1029/2002GB001915, 2003.

Cramer, W., Bondeau, A., Woodward, F. I., Prentice, I. C., Betts, R. A., Brovkin, V., Cox, P. M., Fisher, V., Foley, J. A., Friend, A. D., Kucharik, C., Lomas, M. R., Ramankutty, N., Sitch, S., Smith, B., White, A., and Young-Molling, C.: Global response of terrestrial ecosystem structure and function to $\mathrm{CO}_{2}$ and 
climate change: results from six dynamic global vegetation models, Global Change Biol., 7, 357-373, 2001.

Crockford, R. H. and Richardson, D. P.: Partitioning of rainfall into throughfall, streamflow and interception: effect of forest type, ground cover and climate, Hydrol. Process., 14, 2903-2920, 2000.

Ding, Y. and Dai, X.: Temperature variation in China during the last 100 years, Meteorol. Month., 20, 19-26, 1994.

Fan, S., Gao, Y., Cheng, Y., and Bai, Q.: Rainfall-intercepting capability of forest canopy, Sci. Geogr. Sinica, 27, 200-204, 2007.

Field, C. B., Jackson, R. B., and Mooney, H. A.: Stomatal responses to increased $\mathrm{CO}_{2}$ : implications from the plant to the global scale, Plant Cell Environ., 18, 1214-1225, 1995.

Foley, J. A., DeFries, R., Asner, G. P., Barford, C., Bonan, G., Carpenter, S. R., Chapin, F. S., Coe, M. T., Daily, G. C., Gibbs, H. K., Helkowski, J. H., Holloway, T., Howard, E. A., Kucharik, C. J., Monfreda, C., Patz, J. A., Prentice, I. C., Ramankutty, N., and Snyder, P. K.: Global consequences of land use, Science, 309, 570-574, 2005.

Frederick, K. D. and Major, D. C.: Climate change and water resources, Climate Change, 37, 7-23, 1997.

Gao, X., Zhao, Z., Ding, Y., Huang, R., and Filippo, G.: Climate change due to greenhouse effects in China as simulated by a regional climate model, Adv. Atmos. Sci. 18, 1224-1230, 2001.

Gedney, N., Cox, P. M., Betts, R. A., Huntingford, C., and Stott, P. A.: Detection of a direct carbon dioxide effect in continental river runoff records, Nature, 439, 835-838, 2006.

Gül, G. O., Rosbjerg, D., Gül, A., Ondracek, M., and Dikgola, K.: Assessing climate change impacts on river flows and environmental flow requirements at catchment scale, Ecohydrology, 3, 28-40, 2010.

Guo, H., Qi, H., and Jiang, T.: Annual and seasonal streamflow responses to climate and land-cover changes in the Poyang Lake basin, China, J. Hydrol., 355, 106-122, 2008.

Hay, L. E., Wilby, R. L., and Leavesley, G. H.: A comparison of Delta change and downscaled GCM scenarios for three mountainous basins in the United States, J. Am. Water Resour. Assoc., 36, 387-397, 2000.

Hölscher, D., Köhler, L., van Dijk, A. I. J. M., and Bruijnzeel, L. A.: The importance of epiphytes to total rainfall interception by a tropical montane rain forest in Costa Rica, J. Hydrol., 292, 308322, 2004.

Hu, Q., Feng, S., Guo, H., Chen, G., and Jiang, T.: Interactions of the Yangtze river flow and hydrologic processes of the Poyang Lake, China, J. Hydrol., 347, 90-100, 2007.

Huang, Y. S., Chen, S. S., and Lin, T. P.: Continuous monitoring of water loading of trees and canopy rainfall interception using the strain gauge method, J. Hydrol., 311, 1-7, 2005.

IPCC.: Climate Change 2001: The Scientific Basis. Summary for Policymakers and Technical Summary of Working Group I Report, Cambridge, UK, Cambridge University Press, 2001.

Jackson, R. B., Jobbágy, E. G., Avissar, R., Roy, S. B., Barrett, D., Cook, C. W., Farley, K. A., Maitre, D. C. L., McCarl, B. A., and Murray, B. C.: Trading water for carbon with biological carbon sequestration, Science, 310, 1944-1947, 2005.

Jiang, T. and Shi, Y.: Global warming and its consequences in Yangtze River floods and damages, Adv. Earth Sci., 18, 277-284, 2003.
Jiang, Z.: Analysis and research about loading ability of the water environment of Poyang Lake, Nanchang University, Nanchang, China, 13 pp., 2007.

Ju, W. M., Chen, J. M., Harvey, D., and Wang, S.: Future carbon balance of China's forests under climate change and increasing $\mathrm{CO}_{2}$, J. Environ. Manage., 85, 538-562, 2007.

Kundzewicz, Z. W., Mata, L. J., Arnell, N. W., Döll, P., Kabat, P., Jiménez, B., Miller, K. A., Oki, T., Sen, Z., and Shiklomanov, I. A .: Freshwater resources and their management, in: Climate Change 2007: Impacts, Adaptation and Vulnerability, Contribution of Working Group II to the Fourth Assessment Report of the Intergovernmental Panel on Climate Change, edited by: Parry, M. L., Canziani, O. F., Palutikof, J. P., van der Linden, P. J., and Hanson, C. E., Cambridge University Press, Cambridge, UK, 73210, 2007.

Li, Q., Li, W., Si, P., Gao, X., Dong, W., Jones, P., Huang, J., and Cao, L.: Assessment of surface air warming in northeast China, with emphasis on the impacts of urbanization, Theor. Appl. Climatol., 99, 469-478, 2010.

Lins, H. F. and Slack, J. R.: Streamflow trends in the United States. Geophys. Res. Lett., 26, 227-230, 1999.

Liu, C. and Fu, G.: Analysises of hydrological response to climatic changes in China, in: Climate change and influence, China, edited by: Zhang, Y. and Zhang, P., Meteorological Press, Beijing, China, 205-213, 1993.

Liu, Q. and Cui, B.: Impacts of climate change/variability on the streamflow in the Yellow River Basin, China, Ecol. Model., 222, 268-274, 2009.

Miller, N. L., Bashford, K. E., and Strem E.: Potential impacts of climate change on California hydrology, J. Am. Water Resour. Assoc., 39, 771-784, 2003.

Milly, P. C. D., Dunne, K. A., and Vecchia, A. V.: Global pattern of trends in streamflow and water availability in a changing climate, Nature, 438, 347-350, 2005.

Nash, L. L. and Gleick, P. H.: Sensitivity of streamflow in the Colorado Basin to climate change, J. Hydrol., 125, 221-241, 1991.

Null, S. E., Viers, J. H., and Mount, J. F.: Hydrologic response and watershed sensitivity to climate warming in California's Sierra Nevada, PLoS ONE, 5, 1-16, 2010.

Oki, T. and Kanae, S.: Global hydrological cycles and world water resources, Science, 313, 1068-1071, 2006.

Oki, T., Musiake, K., Matsuyama, H., and Masuda, K.: Global atmospheric water balance and runoff from large river basins, Hydrol. Process., 9, 655-678, 1995.

Piao, S., Friedlingstein, P., Ciais, P., de Noblet-Ducoudré, N., Labat, D., and Zaehle, S.: Changes in climate and land use have a larger direct impact than rising $\mathrm{CO}_{2}$ on global river runoff trends, $\mathrm{P}$. Natl. Acad. Sci., 104, 15242-15247, 2007.

Roderick, M. L. and Farquhar, G. D.: The cause of decreased pan evaporation over the past 50 years, Science, 298, 1410-1411, 2002.

Roderick, M. L. and Farquhar, G. D.: Changes in Australian pan evaporation from 1970 to 2002, Int. J. Climatol., 24, 1077-1090, 2004.

Roderick, M. L. and Farquhar, G. D.: Changes in New Zealand pan evaporation since the 1970s, Int. J. Climatol., 25, 2031-2039, 2005. 
Roderick, M. L., Farquhar, G. D., and Hobbins, M. T.: On the attribution of changing pan evaporation, Geophys. Res. Lett., 34, L17403, doi:10.1029/2007GL031166, 2007.

Shankman, D., Keim, B. D., and Song, J.: Flood frequency in China's Poyang Lake Region: trends and teleconnections, Int. J. Climatol., 26, 1255-1266, 2006.

Sun, S. L., Zhou, S. Q., Song, J., Shi, J. H., Gu, R. Y., and Ma, F. M.: Change in pan evaporation and its driving factors in Jiangxi Province, T. Chin. Soc. Agr. Eng., 26, 59-65, 2010.

The Standing Committee of the National People's Congress (NPC) of the People's Republic of China: The 21st Agenda of China - Population, Environment and Development White Paper, Beijing, China, 1994.

Thodsen, H.: The influence of climate change on stream flow in Danish rivers, J. Hydrol., 333, 226-238, 2007.

Tong, H.: A climatic calculation method for the evaporation power in China, Journal of Nanjing Institute of Meteorology, 12, 20-33, 1989.

Vörösmarty, C. J., Green, P., Salisbury, J., and Lammers, R. B.: Global water resources: vulnerability from climate change and population growth, Science, 289, 284-288, 2000.

Wang, J.: Study on the empirical formula of solar radiation in Jiangxi Province, Jiangxi Energy, 3, 53-56, 2006.

Wang, S. and Dong, D.: Enhancement of the warming trend in China, Geophys. Res. Lett., 27, 2581-2584, 2000.

Wen, Y. and Liu, S.: Quantitative analysis of the characteristics of rainfall interception of main forest ecosystems in China, Scientia Silvae Sinicae, 31, 289-298, 1995.

Xiong, L. and Guo, S.: Trend test and change-point detection for the annual discharge series of the Yangtze River at the Yichang hydrological station, Hydrolog. Sci. J., 49, 99-112, 2004.

Xu, C., Gong, L., Jiang, T., Chen, D., and Singh, V. P.: Analysis of spatial distribution and temporal trend of reference evapotranspiration and pan evaporation in Changjiang (Yangtze River) catchment, J. Hydrol., 327, 81-93, 2006.
Xu, Z., Liu, Z., Fu, G., and Chen, Y.: Trends of major hydroclimatic variables in the Tarim River Basin during the past 50 years, J. Arid Environ., 74, 256-267, 2010.

Yang, X., Zhang, Y., Ding, M., Liu, L., Wang, Z., and Gao, D.: Observation evidence of the impact of vegetation cover on surface air temperature change in China, Chin. J. Geographys., 53, 833841, 2010.

Zhai, P., Chao, Q., and Zou, X.: Progress in China's climate change study in the 20th century, J. Geogr. Sci., 14, 3-11, 2004.

Zhang, J., Dong, W., Wu, L., Wei, J., Chen, P., and Lee, D. K.: Impact of land use changes on surface warming in China, Adv. Atmos. Sci., 22, 343-348, 2005.

Zhang, K., Kimball, J. S., Mu, Q., Jones, L. A., Goetz, S. J., and Running, S. W.: Satellite based analysis of northern ET trends and associated changes in the regional water balance from 1983 to 2005, J. Hydrol., 379, 92-110, 2009.

Zhang, K., Kimball, J. S., Nemani, R. R., and Running, S. W.: A continuous satellite-derived global record of land surface evapotranspiration from 1983-2006, Water Resour. Res., 46, W09522, doi:10.1029/2009WR008800, 2010.

Zhang, W., Xiao, Z., Zheng, J., and Ren, J.: Long-term variation features of streamflow and its response to climate change in $\mathrm{Nu}-$ jiang Basin, Sci. Bull., 52, 135-141, 2007.

Zhang, X., Harvey, K. D., Hogg, W. D., and Yuzyk, T. R.: Trends in Canadian streamflow, Water Resour. Res., 37, 987-998, 2001.

Zhao, F. F. and Xu, Z. X.: Statistical downscaling of future temperature change in source of the Yellow River Basin, Plateau Meteorol., 27, 153-161, 2008.

Zhao, G., Hörmann, G., Fohrer, N., and Zhai, J.: Streamflow trends and climate variability impacts in Poyang Lake Basin, China, Water Resour. Manage., 24, 689-706, 2009. 